\title{
Food crops irrigated with cyanobacteria- contaminated water: an emerging public health issue in Canada
}

\author{
Aroha Miller* and Chris Russell $\dagger$ \\ *British Columbia Centre for Disease Control/National Collaboration Centre for Environmental Health, Vancouver, BC. \\ 'Interior Health, Vernon, BC.
}

Cyanobacteria, commonly but inaccurately known as bluegreen algae, are naturally occurring, single-celled organisms (prokaryotes) (Whitton and Potts, 2012) found in fresh, brackish, and marine waters (Backer et al., 2015) and some soils. It is estimated that there are between 2000 and 8000 species worldwide (Nabout et al., 2013). Cyanobacteria produce oxygen during photosynthesis and were thus fundamental in helping to create the oxygen-rich atmosphere on earth today (Schopf, 2012). Cyanobacteria are also the primary nitrogen fixers in the ocean (Diez et al., 2008). The presence of some secondary metabolites produced by cyanobacteria may enhance productivity of certain agricultural crops (Machado et al., 2017b).

However, cyanobacteria are better known for their detrimental impacts on aquatic ecosystems and human health. Under certain conditions including, but not limited to, warmer water temperatures and high nutrient loads, cyanobacteria can rapidly proliferate and create blooms known as cyanoblooms, harmful algal blooms (HABs), or cyanoHABs. Cyanoblooms can be unsightly, impacting popular tourist destinations, e.g., Lake Erie (Levy, 2017). Their presence can impart an unpleasant odour or taste to the water, and as the bloom dies it may smell of rotting plants.

Even more concerning is the production of cyanotoxins. There are many different types of cyanotoxins; however, some cause more of a public health risk than others. These include nodularin, saxitoxin, cylindrospermopin, and microcystins of which there are almost 100 different variants (Qi et al., 2015). Cyanotoxins are harmful to human health; different toxins target different organ systems, e.g., liver, kidneys, nervous system, and skin (Svircev et al., 2017). Acute exposure causes symptoms such as vomiting, diarrhoea, nausea, skin irritation, rash, fever, headache, weakness, numbness of lips and mouth, incoordination, respiratory and muscular paralyses, and in rare cases death (Svircev et al., 2017). Chronic exposure to microcystins and nodularin can induce tumour-promoting activity, often but not always resulting in liver tumours (IARC Monographs 94, 2010). Microcystin-LR (MC-LR), the most common microcystin

Corresponding author: Aroha Miller (email: aroha.miller@ bccdc.ca). variant, has been classified as Group 2B, possibly carcinogenic to humans (IARC Monographs 94, 2010). Exposure to cyanotoxins occurs via drinking contaminated water, inhalation of steam and aerosolized droplets of contaminated water during showering, skin contact during swimming or showering, consumption of fish or shellfish grown in contaminated water bodies, or consumption of food crops irrigated with contaminated water (Svircev et al., 2017).

Cyanotoxins can bioaccumulate in various food crops irrigated with cyanobacteria-contaminated water (Table 1). There are many variables that can determine to what concentration cyanotoxins bioaccumulate, such as the plant stage when exposed to cyanotoxins (e.g., germination, growing, fruiting adult plant), composition of soil bacteria, concentration of cyanotoxin in the water, amount of water used for irrigation, length of exposure via irrigation, etc. However, the fact that bioaccumulation can occur has raised the question of whether there is a public health risk for people consuming food crops grown under these conditions.

\section{Produce as a vehicle for foodborne illnesses}

Over the last 50 years, food crops have been implicated in an ever-increasing number of foodborne illnesses. Between the 1970 s and 1990s in the United States, the percentage of outbreaks involving fresh produce increased from $0.7 \%$ to $6 \%$ (Sivapalasingam et al., 2004). In the United States between 1998 and 2008, fresh produce was responsible for $46 \%$ of foodborne illnesses (Painter et al., 2013). There is clearly an increasing risk of foodborne illnesses via food crops, and due consideration should thus be given to the water used to irrigate crops. While this risk has historically been due to the role fresh produce plays in the transmission of enteric pathogens, there is a growing body of evidence showing the potential for food crops to bioaccumulate cyanotoxins (Codd et al., 1999; McElhiney et al., 2001; Mohamed and Al Shehri, 2009; Hereman and Bittencourt-Oliveira, 2012; Freitas et al., 2015; Liang and Wang, 2015; Bittencourt-Oliveira et al., 2016; Cordeiro-Araújo et al., 2016; Machado et al., 2017a), potentially resulting in consumer exposure. 
Table 1. Accumulation of microcystins in food crops via irrigation with cyanobacteria-contaminated water. Control doses are not shown.

\begin{tabular}{|c|c|c|c|}
\hline Plant species & Irrigation doses and details & Outcome & Author \\
\hline Lettuce (Lactuca sativa) & $\begin{array}{l}\text { MC-LR } 0.5,2,5,10 \mu \mathrm{g} / \mathrm{L} \\
\text { MC-RR } 0.15,0.5, .5,3 \mu \mathrm{g} / \mathrm{L} \\
\text { Total MC } 0.65,2.5,6.5,13 \mu \mathrm{g} / \mathrm{L} \\
\text { Thirty day old plants given } 100 \mathrm{~mL} \text { of } \\
\text { water daily for } 15 \text { days. Lettuce leaf } \\
\text { tissue analyzed. }\end{array}$ & $\begin{array}{l}\text { No bioaccumulation at lowest } \\
\text { doses. } \\
\text { MC-LR: } 32-143 \mu \mathrm{g} / \mathrm{kg} \mathrm{FW} \\
\text { MC-RR: } 6-15 \mu \mathrm{g} / \mathrm{kg} \mathrm{FW} \\
\text { Total MC: } 39-158 \mu \mathrm{g} / \mathrm{kg} \mathrm{FW}\end{array}$ & $\begin{array}{l}\text { Bittencourt- } \\
\text { Oliveira et al., } \\
2016\end{array}$ \\
\hline Lettuce (Lactuca sativa) & $\begin{array}{l}\text { Specific doses unknown. Irrigation in } \\
\text { a commercial horticulture unit. } \\
\text { MC-LR (bloom and scum): } \\
3.23 \pm 0.11 \mu \mathrm{g} / \mathrm{mg} \\
\text { Lettuce leaf tissue analyzed. }\end{array}$ & $\begin{array}{l}\text { MC-LR: } 94-2487 \mu \mathrm{g} / \mathrm{kg} \mathrm{DW} \\
\text { Cyanobacterial cells not removed } \\
\text { from lettuce leaves by washing/ } \\
\text { rinsing. Crop removed from sale. }\end{array}$ & Codd et al., 1999 \\
\hline $\begin{array}{l}\text { Lettuce (Lactuca sativa), } \\
\text { arugula (Eruca sativa) }\end{array}$ & $\begin{array}{l}\text { MC-LR 5, } 10 \mu \mathrm{g} / \mathrm{L} \\
\text { Arugula ( } 30 \text { day old plants) lettuce } \\
\text { (40 day old plants) irrigated daily with } \\
100 \mathrm{~mL} \text { water for } 7 \text { days, followed by } \\
7 \text { days depuration. } \\
\text { Lettuce leaf tissue analyzed. }\end{array}$ & $\begin{array}{l}\text { MC-LR: } 50-100 \mu \mathrm{g} / \mathrm{kg} \mathrm{FW} \\
\text { (After depuration) MC-LR: } \\
\text { decreased to } 30 \mu \mathrm{g} / \mathrm{kg} \mathrm{FW} \\
\text { MC-LR not detected in arugula. }\end{array}$ & $\begin{array}{l}\text { Cordeiro-Araújo } \\
\text { et al., } 2016\end{array}$ \\
\hline Lettuce (Lactuca sativa) & $\begin{array}{l}\text { Total MC } 2100 \mu \mathrm{g} / \mathrm{L} \text { (from } \\
\text { contaminated lake water). Irrigated } \\
\text { every } 2^{\text {nd }} \text { or } 3^{\text {rd }} \text { day for } 12 \text { days with } \\
100 \mathrm{~mL} \text { water. Leaf and roots analyzed. }\end{array}$ & $\begin{array}{l}\text { MC-LR: } 300-870 \mu \mathrm{g} / \mathrm{kg} \mathrm{DW} \\
\text { (roots) } \\
740-840 \mu \mathrm{g} / \mathrm{kg} \text { DW (shoots) }\end{array}$ & Crush et al., 2008 \\
\hline Lettuce (Lactuca sativa) & $\begin{array}{l}\text { Total MC } 0.62,2.5,6.23,12.5 \mu \mathrm{g} / \mathrm{L} \\
\text { Fully grown plants sprayed with } 100 \\
\mathrm{~mL} \text { water daily for } 15 \text { days. Lettuce } \\
\text { leaf tissue analyzed. }\end{array}$ & $\begin{array}{l}\text { MC-LR: } 8.31-177.8 \mu \mathrm{g} / \mathrm{kg} \mathrm{FW} \\
\text { Greater accumulation at higher } \\
\text { doses. }\end{array}$ & $\begin{array}{l}\text { Hereman and } \\
\text { Bittencourt- } \\
\text { Oliveira, } 2012\end{array}$ \\
\hline $\begin{array}{l}\text { Lettuce (Lactuca sativa), } \\
\text { arugula (Eruca sativa), } \\
\text { cabbage (Brassica sp.), } \\
\text { radish (Raphanus sp.), } \\
\text { dill (Anethum graveolens), } \\
\text { parsley (Petroselinum crispum) }\end{array}$ & $\begin{array}{l}\text { Contaminated groundwater from wells } \\
\text { used, (probably MC-YR) ranged from } \\
0.3 \text { to } 1.8 \mu \mathrm{g} / \mathrm{L} \text {. } \\
\text { Leaves and roots of all plants analyzed. }\end{array}$ & $\begin{array}{l}\text { Lettuce: }<100-\sim 400 \mu \mathrm{g} / \mathrm{kg} \mathrm{FW} \\
\text { Arugula: }<100-\sim 400 \mu \mathrm{g} / \mathrm{kg} \mathrm{FW} \\
\text { Cabbage: }<100-\sim 800 \mu \mathrm{g} / \mathrm{kg} \mathrm{FW} \\
\text { Radish: }<300-1200 \mu \mathrm{g} / \mathrm{kg} \mathrm{FW} \\
\text { Dill: } \sim 150-800 \mu \mathrm{g} / \mathrm{kg} \mathrm{FW} \\
\text { Parsley: } 300-800 \mu \mathrm{g} / \mathrm{kg} \mathrm{FW} \\
\text { Roots accumulated higher } \\
\text { concentrations compared to leaves, } \\
\text { with the exception of dill. } \\
\end{array}$ & $\begin{array}{l}\text { Mohamed and } \\
\text { Al Shehri, } 2009\end{array}$ \\
\hline $\begin{array}{l}\text { Broccoli (Brassica oleracea), } \\
\text { mustard (Sinapis alba) }\end{array}$ & $\begin{array}{l}\text { Total MC (LR and RR) } 1,10 \mu \mathrm{g} / \mathrm{L} \\
\text { Mustard exposure } 19 \text { days } \\
\text { Broccoli exposure } 20 \text { days }\end{array}$ & $\begin{array}{l}\text { Only MC-LR detected in plant } \\
\text { roots. } \\
\text { Broccoli: } 0.9-2.4 \mu \mathrm{g} / \mathrm{kg} \mathrm{FW} \\
\text { Mustard: } 2.5-2.6 \mu \mathrm{g} / \mathrm{kg} \mathrm{FW} \\
\end{array}$ & $\begin{array}{l}\text { Järvenpää et al., } \\
2007\end{array}$ \\
\hline Rice (Oryza sativa) & $\begin{array}{l}\text { MC-LR 24, 120, } 600,3000 \mu \mathrm{g} / \mathrm{L} \\
\text { Germination tests. Rice seeds soaked } \\
\text { for } 24 \text { hrs then laid in boxes lined with } \\
\text { paper saturated with } 10 \mathrm{~mL} \text { of each } \\
\text { dose. } 4 \mathrm{~mL} \text { of each dose was added at } \\
3 \text { day intervals. Continued for } 10 \text { days. } \\
\text { Seedlings analyzed. }\end{array}$ & $\begin{array}{l}\text { MC-LR (lowest dose) not detected } \\
\text { (highest dose) } 29.4-54 \mu \mathrm{g} / \mathrm{kg} \mathrm{FW}\end{array}$ & Chen et al., 2004 \\
\hline $\begin{array}{l}\text { Tomatoes (Lycopersicon } \\
\text { esculentum) }\end{array}$ & $\begin{array}{l}\text { MC-LR } 100 \mu \mathrm{g} / \mathrm{L} \\
\text { Plants irrigated every } 3^{\text {rd }} \text { day for } \\
2 \text { weeks with } 500 \mathrm{~mL} \text { water. Leaves, } \\
\text { fruit (green and mature), roots were } \\
\text { collected and analyzed after } 2 \text { weeks. }\end{array}$ & $\begin{array}{l}\text { MC-LR (after } 1 \text { week) only } \\
\text { detected in green and mature } \\
\text { tomato: } 5.4 \text { and } 10.8 \mu \mathrm{g} / \mathrm{kg} \mathrm{FW} \text {, } \\
\text { respectively. } \\
\text { MC-LR below detection limit after } \\
2 \text { weeks of irrigation in all } \\
\text { measured parts of the plant. }\end{array}$ & $\begin{array}{l}\text { Gutiérrez-Praena } \\
\text { et al., } 2014\end{array}$ \\
\hline Carrots (Daucus carota) & $\begin{array}{l}\text { MC-LR } 10,50 \mu \mathrm{g} / \mathrm{L} . \text { Carrots grown for } \\
1 \text { month and then irrigated for } 32 \text { days. }\end{array}$ & MC-LR: $5 \mu \mathrm{g} / \mathrm{kg} \mathrm{FW}$ & $\begin{array}{l}\text { Machado et al., } \\
2017 \text { a }\end{array}$ \\
\hline
\end{tabular}




\section{Cyanotoxins can bioaccumulate in food crops}

Cyanobacteria, specifically MC-LR, can bioaccumulate in various food crops irrigated with cyanobacteria-contaminated water (Codd et al., 1999; Chen et al., 2004; Järvenpää et al., 2007; Crush et al., 2008; Mohamed and Al Shehri, 2009; Hereman and BittencourtOliveira, 2012; Gutierrez-Praena et al., 2014; Bittencourt-Oliveira et al., 2016; Cordeiro-Araújo et al., 2016; Machado et al., 2017a). Concentrations measured in plants are dependent on the concentrations in the water used for irrigation (Hereman and BittencourtOliveira, 2012). For example, MC-LR accumulated in lettuce leaf tissue grown in potted soil under laboratory conditions at concentrations of up to $143 \mu \mathrm{g} / \mathrm{kg}$ after irrigation for 15 days with $100 \mathrm{~mL}$ water containing $10 \mu \mathrm{g} / \mathrm{L} \mathrm{MC}-\mathrm{LR}$. However, very low doses, i.e., 0.5 and $0.65 \mu \mathrm{g} / \mathrm{L}$, did not show bioaccumulation of MC-LR in lettuce leaf tissue (Bittencourt-Oliveira et al., 2016). After only 7 days of irrigation with $100 \mathrm{~mL}$ water containing $10 \mu \mathrm{g} / \mathrm{L}$ MC-LR in a laboratory setting, lettuce leaf tissue concentrations of up to $100 \mu \mathrm{g} / \mathrm{kg}$ fresh weight were seen (Cordeiro-Araújo et al., 2016). Researchers were made aware of a situation where crops were being spray irrigated with contaminated water under actual farm conditions. Accordingly, actual concentrations in the irrigation water were not reported. Nonetheless, MC-LR in lettuce leaf tissue reached between 94 and 2,487 $\mu \mathrm{g} / \mathrm{kg}$ dry weight ( $1 \mathrm{~g}$ of dry weight is equivalent to $10 \mathrm{~g}$ fresh weight), and cyanobacterial cells were not able to be washed off the lettuce leafs, thus reporting in dry weight increases observed concentrations. Subsequently, this batch of produce was not sold (Codd, 1999).

Studies of broccoli and mustard (Sinapis alba) showed MC-LR was only detected in the roots of the plants at low concentrations, e.g., 2.4 and $2.6 \mu \mathrm{g} / \mathrm{g}$ fresh weight, respectively (Järvenpää et al., 2007). Considering the part of the plant that is consumable, these concentrations would not pose a health risk. In contrast, Machado et al. (2017a) detected MC-LR in carrots at $5 \mu \mathrm{g} / \mathrm{kg}$ fresh weight, where the root is the edible portion. Mohamed and Al Shehri (2009) detected total MC in both leaves and roots of the plants they examined. Overall, the roots accumulated much higher concentrations of MC compared with the leaves; however, for some plants, e.g., radish, carrot, yams, beets, it is the root that is consumed, thus presenting a greater risk.

Clear differences in study conditions exist, which may explain some of the observed results. For example, only one study was under natural conditions (Codd et al., 1999). One germination experiment irrigated seedlings with MC-LR concentrations that do not reflect ecologically relevant concentrations, i.e., the highest dose used was $3000 \mu \mathrm{g} / \mathrm{L}$ (Chen et al., 2004). Some studies were conducted under hydroponic conditions (Gutierrez-Praena et al., 2014), whereas others used potted soil or sand (Järvenpää et al., 2007; Crush et al., 2008; Hereman and Bittencourt-Oliveira, 2012; Bittencourt-Oliveira et al., 2016; Cordeiro-Araújo et al., 2016; Machado et al., 2017a). Soil can retain up to $57 \%$ of the toxin bioavailable to the plant (Machado et al., 2017b); however, there is a lack of controlled studies conducted under field conditions using ecologically relevant concentrations.

\section{Lack of policy and regulation in Canada}

Health Canada has set a maximum acceptable concentration (MAC) of $1.5 \mu \mathrm{g} / \mathrm{L}$ for MC-LR in drinking water and $20 \mu \mathrm{g} / \mathrm{L}$ for MC-LR in recreational water bodies (Health Canada, 2016). There are no MACs set for any other cyanotoxin in drinking water and no guidelines or regulations set on MC-LR in water used for the irrigation of food crops. Of the small volume of primary research conducted within the examined period on bioaccumulation of MC-LR in food crops, none has been conducted in Canada.

The Canadian Water Quality Guidelines (Canadian Council of Ministers of the Environment, 2008) provide some guidance for irrigation water quality. However, their focus is primarily on physical and chemical parameters, e.g., heavy metals; plant, human, and animal pathogens; and how these affect crops. Emerging toxins, such as MC-LR, are not discussed. However, there is a framework in place for developing new guidelines that could be included in future updates (Canadian Council of Ministers of the Environment, 1999).

Furthermore, in Canada, legislation that addresses the quality of irrigation water is lacking. For example, the Fresh Fruit and Vegetable Regulations (C.R.C., c. 285) under the Agricultural Products Act stipulates that water used for post-harvest washing and rinsing must be potable, but it does not provide any requirements for irrigation water. This federal legislation applies to produce that is imported, exported, or shipped between provinces. Where there is a lack of legislation, producers are encouraged to follow better practices. A brief survey of materials from various provinces yielded documents that provided similar advice, with a focus on microbial quality and emphasis on the washing and rinsing stages (British Columbia Ministry of Agriculture, 2009; Jones and Shortt, 2010; Alberta Agriculture and Forestry, 2012).

In 1999, the World Health Organization (WHO) established a tolerable daily intake (TDI) of $0.04 \mu \mathrm{g} \mathrm{MC-LR/kg} \mathrm{body} \mathrm{weight}$ (BW) (World Health Organization et al., 1999). Some of the studies mentioned above (Mohamed and Al Shehri, 2009; Hereman and Bittencourt-Oliveira, 2012; Machado et al., 2017a) found MC-LR concentrations in food crops at levels high enough to exceed the WHO TDI, raising concerns about public health risks from consuming food crops irrigated with MC-LR contaminated water. The US FDA guidelines on agricultural water used for irrigation refer only to E. coli and microbial quality, not to cyanobacteria-contaminated water (US Food and Drug Administration, 2017). However, frequently asked questions about cyanobacteria posted by Oregon Public Health (Oregon Health Authority, 2015) noted that if any of the four cyanotoxins they monitor (anatoxin-a, cylindrospermopsin, microcystins, or saxitoxins) are above their drinking water guidelines, then the water should not be used for washing, preparing, or cooking food, nor should it be used for irrigating food crops. However, if below their guidelines $(1.6 \mu \mathrm{g} / \mathrm{L}$ for microcystins for people over 6 years old), water can be used to irrigate food crops as long as contaminated water on any crops is allowed to dry completely in sunlight before consuming and measures are taken to ensure no children or animals drink the water.

\section{Climate change as an exacerbating factor}

Certain climactic conditions can facilitate the formation of cyanoblooms. These include warmer water temperatures, a condition under which cyanobacteria can rapidly proliferate; a decrease in water stratification, which favours cyanobacterial growth and survival; and longer cyanobacterial growing seasons 
(Pick, 2016). An increase in extreme weather events, such as droughts, introduces competition for scarce water resources and drives cyanobacterial growth in diminished water bodies. Resource competition may lead to an increase in greywater use for food crop irrigation, which may improve household food security (Rodda et al., 2011) but can also result in irrigation with microbially contaminated water.

Flooding from increased precipitation (Trenberth, 2011) can increase terrestrial run-off, including sewage overflows into water bodies, thus increasing nutrient loads (Hamilton et al., 2016), driving cyanobacterial growth. Climate change is also implicated in the range expansion of cyanobacteria species (Pick, 2016); blooms and toxins that did not previously occur begin to appear where they were never before observed. In Canada, rapid warming of northern latitudes means areas once largely unaffected by cyanobacteria may now be at risk (Pick, 2016). However, to date research examining the impact of climate change on cyanobacteria in the context of food crop irrigation and within a Canadian context, i.e., the northern latitude, is lacking.

\section{Knowledge gaps}

There is a lack of field-based experiments examining irrigation of food crops under real conditions. Some research indicates various soil types adsorb cyanotoxins, reducing toxin bioavailability to plants, and that certain soil bacteria species can biodegrade cyanotoxins (Corbel et al., 2014). However, whether or not there are geographic differences in soil bacteria species present in Canada and if they are capable of degrading cyanotoxins requires further investigation.

The literature focuses on microcystin research and largely neglects the bioaccumulation of other cyanotoxins into food crops, because microcystins are generally regarded as the most important of the cyanotoxins (Health Canada, 2016). Research is lacking on the frequency and intensity of watering; different delivery methods, e.g., spray, drip, or sprinkle irrigation; as well as risks to farm workers from these delivery methods, i.e., inhalation of water from spray irrigation. Only one study on depuration (the excretion or metabolic breakdown of toxins) was found and this examined only two species, lettuce and arugula (Cordeiro-Araújo et al., 2016). Further depuration work on a wider range of food crops is necessary. Given the variability in results presented above, a wider range of food crops, including fruit and berries, should be examined, preferably with a focus on the edible portions. Work to investigate possible biotransformation of cyanotoxins would also be of use.

It should be noted that research on irrigation of food crops with cyanobacteria-contaminated water is lacking in a Canadian context within the examined period. None of the studies on bioaccumulation in food crops were conducted within Canada. Microcystins have now been detected in lakes in every Canadian province over the last decade (Orihel et al., 2012), thus there is a need for evidence to inform us as we move forward.

\section{Future directions}

The consumption of food crops irrigated with cyanobacteria (MC-LR)-contaminated water is an emergent area with public health implications. Not enough is known about how this issue might affect Canadian consumers, especially in regard to changing climactic conditions; thus, it seems timely to address the issue with Canadian research and knowledge synthesis. Moving forward, suggested research and policy-enabling directions may include:

- research addressing issues specific to Canadian geography, climate, and physical conditions around the contamination of food crops irrigated with cyanobacteria-contaminated water;

- the development of Canadian regulations or guidelines for MC-LR in irrigation water intended for food crops;

- to increase awareness among food producers of the emerging risk that cyanobacterial toxins such as MC-LR pose to their consumers;

- to increase knowledge through education campaigns among food producers that helps them to determine when an irrigation water source may be at risk of containing cyanotoxins, how to use test kits to check for their presence, and next steps to take if cyanotoxins are detected; and

- to highlight the role that environmental health officers (EHO) and public health professionals have in aiding this effort through education and consultation.

Practical recommendations cannot be made until evidence-based research, preferably conducted in Canada, is available to inform us. For example, research on the use of different irrigation systems, e.g., use of drip irrigation or canals, rather than spray irrigation; refraining from use of contaminated water for set periods prior to harvesting to allow depuration; or treatment of water used for irrigation. In the meantime, increasing awareness and education amongst food producers, EHOs, and other public health professionals, of the risk posed by the use of cyanobacteria-contaminated irrigation water is suggested.

\section{Methods}

To inform this article, recently published scientific literature and relevant government, agency, and grey literature was scoped using the following methods.

Literature was identified through Medline, CINAHL, Biomedical Reference Collection, Web of Science, and Google Scholar. Emphasis was placed on scientific articles published within the last five years; however, older articles were included if they appeared relevant. An initial search was conducted within the context of cyanobacteria and health, using the terms:

- Cyanobacteri OR Cyanophyta OR "blue-green bacteria” OR cyanoHAB OR "harmful algal bloom" OR cyanotoxin OR microcystin OR "Anatoxin-a producing Tychonema") AND (health OR illness disease OR e-coli OR legionnaire OR crypto OR shigell ${ }^{*}$ OR fowleri OR amoeba OR norovirus $\mathrm{OR}$ bacterium $\mathrm{OR}$ endotoxin $\mathrm{OR}$ respiratory $\mathrm{OR}$ cancer OR inflammation)

- (rule OR guidance OR guideline OR regulation OR operation OR legislation)

- (advisory OR notification OR restriction OR limit OR response)

- (risk OR assessment OR mitigation OR management). 
This search turned up 117 related articles/documents. The titles and abstracts were scanned to assess their relevance to this context. A second, more context-specific search was conducted. Terms included:

- Cyanobacteri OR Cyanophyta OR "blue-green bacteria" OR cyanoHAB OR "harmful algal bloom" OR cyanotoxin OR microcystin OR "Anatoxin-a producing Tychonema") AND agricultur* OR farming OR vegetable OR garden OR irrigat* OR harvest

This search turned up 28 related articles, of which 10 specifically examined the bioaccumulation of cyanotoxins in food crops.

One further search was conducted to look for Canadianspecific literature, using the terms:

- (cyanobacteria OR cyanophyta OR "blue-green bacteria" OR cyanohab OR "harmful algal bloom" OR cytotoxin OR microcystin OR "Anatoxin-a producing Tychonema") AND (canad* OR "british columbia" OR coast OR atlantic) AND (agricultur* OR farming OR vegetable OR garden OR irrigat* OR crop OR harvest OR plant).

This search turned up 6 articles, which were not specifically relevant to this context.

\section{Acknowledgements}

The authors would like to thank Lydia Ma, Manager, National Collaborating Centre of Environmental Health (NCCEH), for her input, and Michele Wiens, Information Specialist, NCCEH for conducting the literature searches.

\section{References}

Alberta Agriculture and Forestry. 2012. Irrigation water quality safety for fresh field-grown fruits and vegetables. Available at: http:// www1.agric.gov.ab.ca/\$department/deptdocs.nsf/all/irr14171 [accessed 10 July 2017].

Backer, L., Manassaram-Baptiste, D., LePrell, R., and Bolton, B. 2015. Cyanobacteria and algae blooms: Review of health and environmental data from the harmful algal bloom-related illness surveillance system (HABISS) 2007-2011. Toxins. 7(4): 1048-1064. doi: $10.3390 /$ toxins 7041048

Bittencourt-Oliveira M., C., Cordeiro-Araújo, M. K., Chia, M. A., Arruda-Neto, J. D., de Oliveira, E. T., and dos Santos, F. 2016. Lettuce irrigated with contaminated water: Photosynthetic effects, antioxidative response and bioaccumulation of microcystin congeners. Ecotoxicol. Environ. Saf. 128: 83-90. doi: 10.1016/j. ecoenv.2016.02.014

British Columbia Ministry of Agriculture. 2009. Good agricultural practices. Available at: http://www2.gov.bc.ca/gov/content/industry/agriculture-seafood/food-safety/good-agricultural-practices. [Accessed 28 June 2017].

Council of Ministers of the Environment. 1999. Canadian water quality guidelines for the protection of agricultural water uses. Available at: http://ceqg-rcqe.ccme.ca/download/en/131. [Accessed 28 June 2017].
Canadian Council of Ministers of the Environment. 2008. Canadian water quality guidelines. Available at: http://www.ccme.ca/files/ Resources/supporting_scientific_documents/cwqg_pn_1040.pdf. [Accessed 28 June 2017].

Chen, J., Song, L., Dai, J., Gan, N., and Liu, Z. 2004. Effects of microcystins on the growth and the activity of superoxide dismutase and peroxidase of rape (Brassica napus L.) and rice (Oryza sativa L. Toxicon. 43(4): 393-400. doi: 10.1016/j.toxicon.2004.01.011

Codd, G. A., Metcalf, J. S., and Beattie, K. A. 1999. Retention of Microcystis aeruginosa and microcystin by salad lettuce (Lactuca sativa) after spray irrigation with water containing cyanobacteria. Toxicon. 37(8): 1181-1185.

Corbel, S., Bouaïcha, N., and Mougin, C. 2014. Dynamics of the toxic cyanobacterial microcystin-leucine-arginine peptide in agricultural soil. Environ. Chem. Lett. 12(4): 535-541. doi: 10.1007/ s10311-014-0482-2

Cordeiro-Araújo, M. K., Chia, M. A., Arruda-Neto, J. D., Tornisielo, V. L., Vilca, F. Z., and Bittencourt-Oliveira Mdo, C. 2016. Microcystin-LR bioaccumulation and depuration kinetics in lettuce and arugula: Human health risk assessment. Sci. Tot. Environ. 566-567: 1379-1386. doi: 10.1016/j.scitotenv.2016.05.204

Crush, J. R., Briggs, L. R., Sprosen, J. M., and Nichols, S. N. 2008. Effect of irrigation with lake water containing microcystins on microcystin content and growth of ryegrass, clover, rape, and lettuce. Environ. Toxicol. 23(2): 246-252. doi: 10.1002/ tox. 20331

Diez, B., Bergman, B., and El-Shehway, R. 2008. Marine diazotrophic cyanobacteria: Out of the blue. Plant Biotechnol. 25(3): 221-225. doi: $10.5511 /$ plantbiotechnology.25.221

Food and Drug Administration. 2017. Standards for the growing, harvesting, packing, and holding of produce for human consumption. Available at: https://www.fda.gov/food/guidanceregulation/fsma/ ucm334114.htm [accessed 23 June 2017].

Freitas, M., Azevedo, J., Pinto, E., Neves, J., Campos, A., and Vasconcelos, V. 2015. Effects of microcystin-LR, cylindrospermopsin and a microcystin-LR/cylindrospermopsin mixture on growth, oxidative stress and mineral content in lettuce plants (Lactuca sativa L.). Ecotoxicol.Environ. Saf. 116:59-67. doi: 10.1016/j.ecoenv.2015.02.002

Gutierrez-Praena, D., Campos, A., Azevedo, J., Neves, J., Freitas, M., Guzman-Guillen, R., Cameán, A. M., Renaut, J., and Vasconcelos, V. 2014. Exposure of Lycopersicon esculentum to microcystin-LR: Effects in the leaf proteome and toxin translocation from water to leaves and fruits. Toxins. 6(6): 1837-1854. doi: 10.3390/ toxins 6061837

Hamilton, D. P., Salmaso, N., and Paerl, H. W. 2016. Mitigating harmful cyanobacterial blooms: Strategies for control of nitrogen and phosphorus loads. Aquat Ecol. 50(3): 351-366. doi: 10.1007/ s10452-016-9594-z

Health Canada. 2016. Cyanobacterial toxins in drinking water - Document for public consultation. Available at: https://www.canada. $\mathrm{ca} /$ en/health-canada/programs/cyanobacterial-toxins-drinking-water/cyanobacterial-toxins-drinking-water.html. [Accessed 5 June 2017].

Health Organization, UNESCO, and UNEP. 1999. Toxic cyanobacteria in water. Chapter 5 Safe levels and safe practices. Great Britain: St. Edmundsbury Press, Lyon, France.

Hereman, T., and Bittencourt-Oliveira, M. 2012. Bioaccumulation of microcystins in lettuce. J. Phycol. 48(6): 1535-1537. doi: 10.1111/ jpy.12006 
IARC Monographs 94. 2010. Cyanobacterial peptide toxins (p. 86). International Agency for Research on Cancer.

Järvenpää, S., Lundberg-Niinisto, C., Spoof, L., Sjovall, O., Tyystjarvi, E., and Meriluoto, J. 2007. Effects of microcystins on broccoli and mustard, and analysis of accumulated toxin by liquid chromatography-mass spectrometry. Toxicon. 49(6): 865-874. doi: 10.1016/j. toxicon.2006.12.008

Jones, S., and Shortt, R. 2010. Improving on-farm safety through good irrigation practices. Available at: http://www.omafra.gov.on.ca/english/crops/facts/10-037.htm [accessed 10 July 2017].

Levy, S. 2017. Microcystis rising: Why phosphorus reduction isn't enough to stop cyanoHABs. Environ. Health Perspect. 125(2): A34-A39. doi: 10.1289/ehp.125-A34

Liang, C., and Wang, W. 2015. Response and recovery of rice (Oryza sativa) seedlings to irrigation with microcystin-contaminated water. Environ. Earth Sci. 73(8): 4573-4580. doi: 10.1007/ s12665-014-3746-z

Machado, J., Azevedo, J., Freitas, M., Pinto, E., Almeida, A., Vasconcelos, V., and Campos, A. 2017a. Analysis of the use of microcystincontaminated water in the growth and nutritional quality of the root-vegetable, Daucus carota. Environ. Sci. Pollut. Res. Int. 24(1): 752-764. doi: 10.1007/s11356-016-7822-7

Machado, J., Campos, A., Vasconcelos, V., and Freitas, M. 2017b. Effects of microcystin-LR and cylindrospermopsin on plant-soil systems: A review of their relevance for agricultural plant quality and public health. Environ. Res. 153: 191-204. doi: http://doi. org/10.1016/j.envres.2016.09.015

McElhiney, J., Lawton, L. A., and Leifert, C. 2001. Investigations into the inhibitory effects of microcystins on plant growth, and the toxicity of plant tissues following exposure. Toxicon. 39(9): 1411-1420.

Mohamed, Z. A., and Al Shehri, A. M. 2009. Microcystins in groundwater wells and their accumulation in vegetable plants irrigated with contaminated waters in Saudi Arabia. J. Hazard Mater. 172(1): 310-315. doi: 10.1016/j.jhazmat.2009.07.010

Nabout, J.C., Rocha, B.D., Carneiro, F.M., and Sant'Anna, C.L. 2013. How many species of cyanobacteria are there? Using a discovery curve to predict the species number. Biodivers. Conserv. 22(12): 2907-2918. doi: 10.1007/s10531-013-0561-x

Oregon Health Authority. 2015. Cyanotoxins in drinking water Frequently asked questions. Available at: http://www.oregon.
gov/oha/ph/HealthyEnvironments/DrinkingWater/Monitoring/ HealthEffects/Pages/cyanotoxins.aspx [accessed 23 June 2017]

Orihel, D. M., Bird, D. F., Brylinsky, M., Chen, H. R., Donald, D. B., Huang, D. Y., Giani, A., Kinniburgh, D., Kling, H., Kotak, B. G. 2012. High microcystin concentrations occur only at low nitrogen-to-phosphorus ratios in nutrient-rich Canadian lakes. Can. J. Fish Aquat. Sci. 69(9): 1457-1462. doi: 10.1139/f2012-088

Painter, J. A., Hoekstra, R. M., Ayers, T., Tauxe, R. V., Braden, C. R., Angulo, F. J., and Griffin, P. M. 2013. Attribution of foodborne illnesses, hospitalizations, and deaths to food commodities by using outbreak data, United States, 1998-2008. Emerg. Infect. Dis. 19(3): 407-415. doi: 10.3201/eid1903.111866

Pick, F. R. 2016. Blooming algae: A Canadian perspective on the rise of toxic cyanobacteria. Can. J. Fish Aquat. Sci. 73(7): 1149-1158. doi: $10.1139 /$ cjfas-2015-0470

Qi, Y. L., Rosso, L., Sedan, D., Giannuzzi, L., Andrinolo, D., and Volmer, D. A. 2015. Seven new microcystin variants discovered from a native Microcystis aeruginosa strain - Unambiguous assignment of product ions by tandem mass spectrometry. Rapid Commun. Mass Spectr. 29(2): 220-224. doi: 10.1002/rcm.7098

Rodda, N., Salukazana, L., Jackson, S. A. F., and Smith, M. T. 2011. Use of domestic greywater for small-scale irrigation of food crops: Effects on plants and soil. Phys. Chem. Earth. Parts A/B/C. 36(14): 1051-1062. doi: http://dx.doi.org/10.1016/j.pce.2011.08.002

Schopf, J. 2012. The fossil record of cyanobacteria. . In Whitton, B. A. (Ed.), Ecology of cyanobacteria II: Their diversity in time and space (p. 759). Springer, Dordrecht, Netherlands.

Sivapalasingam, S., Friedman, C., Cohen, L., and Tauxe, R. 2004. Fresh produce: A growing cause of outbreaks of foodborne illness in the United States, 1973 through 1997. J. Food Protect. 67(10): 2342-2353. doi: 10.4315/0362-028x-67.10.2342

Svircev, Z., Drobac, D., Tokodi, N., Mijovic, B., Codd, G. A., and Meriluoto, J. 2017. Toxicology of microcystins with reference to cases of human intoxications and epidemiological investigations of exposures to cyanobacteria and cyanotoxins. Arch. Toxicol. 91(2): 621-650. doi: 10.1007/s00204-016-1921-6

Trenberth, K. E. 2011. Changes in precipitation with climate change. Clim. Res. 47(1/2): 123-138.

Whitton, B., and Potts, M. 2012. Introduction to the cyanobacteria. In Whitton, B. A. (Ed.), Ecology of cyanobacteria II: Their diversity in space and time (p. 759). Springer, Dordrecht, Netherlands. 